\title{
Cytogenetic alterations in ovarian clear cell carcinoma detected by comparative genomic hybridisation
}

\author{
J Dent*,', GD Hall', N Wilkinson', TJ Perren', I Richmond ${ }^{2}$, AF Markham ${ }^{3}$, H Murphy ${ }^{4}$ and SM Bell ${ }^{3}$ \\ 'Cancer Research UK Clinical Cancer Centre in Leeds, St James's University Hospital, Leeds LS9 7TF, UK; ' ${ }^{2}$ Hull Royal Infirmary, Hull HU3 2JZ, UK; \\ ${ }^{3}$ Molecular Medicine Unit, University of Leeds, St James's University Hospital, Leeds LS9 7TF, UK; ${ }^{4}$ Academic Unit of Pathology, University of Leeds, Leeds \\ LSI 3EX, UK
}

\begin{abstract}
Ovarian clear cell carcinoma (OCCC) accounts for a small but significant proportion of all ovarian cancers and is a distinct clinical and pathological entity. It tends to be associated with poorer response rates to chemotherapy and with a worse prognosis. Little is known about possible underlying genetic changes. DNA extracted from paraffin-embedded samples of I 8 pure OCCC cases was analysed for genetic imbalances using comparative genomic hybridisation ( $\mathrm{CGH}$ ). All of the 18 cases showed genomic alterations. The mean number of alterations detected by CGH was 6 (range I - 15) indicating a moderate level of genetic instability. Chromosome deletions were more common than amplifications. The most prominent change involved chromosome 9 deletions in 10 cases (55\%). This correlates with changes seen in other epithelial ovarian cancers. This deletion was confirmed using microsatellite markers to assess loss of heterozygosity $(\mathrm{LOH})$ at four separate loci on chromosome 9. The most distinct region of loss detected was around the IFNA marker at 9p2I with $41 \%$ (I I out of 27cases) LOH. Other frequent deletions involved Ip (five out of I 8; 28\%); I I q (four out of I 8; $22 \%$ ) and 16 (five out of I 8; 28\%). Amplification was most common at chromosome 3 (six out of I 8; 33\%); I3q (four out of I 8; 22\%) and 15 (three out of 18; 17\%). No high-level amplifications were identified. These features may serve as useful prognostic indicators in
\end{abstract} the management of OCCC.

British Journal of Cancer (2003) 88, I578- 1583. doi:I0.1038/sj.bjc.6600896 www.bjcancer.com

(c) 2003 Cancer Research UK

Keywords: clear cell ovarian; $\mathrm{CGH}$; LOH; chromosome 9

Ovarian malignancy is the fourth leading cause of death from cancer in women in the UK, and demonstrates an overall 5-year survival rate of $33 \%$ (Gatta et al, 1998). The common histological subtypes of epithelial ovarian cancer are serous, mucinous and endometrioid, which together account for more approximately $85 \%$ of cases (Clark et al, 2001). Clear cell ovarian carcinoma is a less common subtype of ovarian cancer and accounts for $5-10 \%$ of all ovarian malignancies (Kennedy et al, 1989). Although morphologically distinct, ovarian clear cell carcinoma (OCCC) remains controversial in terms of pathological characteristics and grading, response to treatment and overall prognosis.

The identification of clear cell histology has been shown to be an indicator of poor prognosis in many studies (Sugiyama et al, 2000; Clark et al, 2001), with an inferior response to platinum-based chemotherapy (Goff et al, 1996) and an increased incidence of cancer-related complications, such as thromboembolic disease (Recio et al, 1996) and malignancy-related hypercalcaemia (Koshiyama et al, 1999). Although other studies have contested this view (O’Brien et al, 1993), many clinicians consider clear cell histology as an indication for chemotherapy in patients with otherwise low-risk disease (FIGO stage Ia/Ib).

Cytogenetic and molecular analysis of ovarian cancers has detected a number of structural cytogenetic abnormalities. Published karyotypic analyses have tended to include epithelial

*Correspondence: Dr JT Dent, E-mail: drjodent@hotmail.com Received 20 June 2002; revised 14 January 2003; accepted 29 January 2003 ovarian cancers of all histological subtypes and have shown frequent abnormalities of chromosomes 1, 3, 6, 11, 17 and 19, with less frequent abnormalities of chromosomes 2, 4, 5, 9 and 21 (Gallion et al, 1990; Taetle et al, 1999; Roberts and Tattersall, 1990). The development of improved molecular techniques including the use of polymorphic genetic markers has provided more precise ways to identify these genetic abnormalities.

Comparative genomic hybridisation (CGH) is an analytical technique using a single hybridisation with an equal mixture of distinct fluorescently labelled normal and tumour DNA that permits identification of regions of chromosomes that have undergone either an increase or a decrease in DNA amount, causing genomic imbalance in the tumour. Thus, it can be used to examine the entire genome for amplifications and deletions using extracted tumour DNA (Kallioniemi et al, 1992; Visakorpi, 1995).

Comparative genomic hybridisation analysis has revealed numerous cytogenetic changes in epithelial ovarian cancers (Sonoda et al, 1997) with common sites of amplification, in order of frequency, at $8 \mathrm{q}, 20 \mathrm{q}, 3 \mathrm{q}, 1 \mathrm{q}, 20 \mathrm{p}, 9 \mathrm{p}$ and $12 \mathrm{p}$ along with deletions at $5 \mathrm{q}, 9 \mathrm{q}, 17 \mathrm{p}, 4 \mathrm{q}, 16 \mathrm{q}$ and $22 \mathrm{q}$. Comparative genomic hybridisation has detected aberrations that correlate with ovarian tumour grade including deletions at chromosome $11 \mathrm{p}$ and $13 \mathrm{q}$, and amplifications at $8 \mathrm{q}$ and $7 \mathrm{p}$ in poorly differentiated tumours as compared with $12 \mathrm{p}$ deletions and $18 \mathrm{p}$ amplifications in well- and moderately differentiated tumours (Kiechle et al, 2001). Some evidence suggests that the main different histological subtypes (serous, mucinous and endometrioid) have different copy number karyotypes, with gains more frequently noted at $10 \mathrm{q}$ and $11 \mathrm{q}$ in 
endometrioid and serous tumours respectively and at $17 \mathrm{q}$ in mucinous tumours (Tapper et al, 1997).

Previously published cytogenetic analyses of ovarian cancer have included very few cases with clear cell histology. The aim of this study was therefore to characterise the genetic alterations of a cohort of pure clear cell ovarian tumours.

\section{MATERIALS AND METHODS}

\section{Tumour samples}

Cases of pure clear cell carcinoma of the ovary were identified from the pathological archives of three specialist cancer hospitals (St James's University Hospital, Leeds General Infirmary and Hull Royal Infirmary). All cases were reviewed and clear cell morphology confirmed independently by two expert gynaecological pathologists (NW and IR). Demographic and survival data were collected anonymously.

\section{DNA extraction}

DNA was extracted from paraffin-embedded samples using standard techniques (Jackson et al, 1990). Briefly, $10 \mu \mathrm{m}$ tumour sections were cut from paraffin wax samples. Sections were dewaxed in xylene and rehydrated through graded alcohol. Relevant areas of individual sections were selected manually, dissected and then digested for 5 days at $37^{\circ} \mathrm{C}$ with proteinase $\mathrm{K}\left(0.1 \mathrm{mg} \mathrm{ml}^{-1}\right.$, Sigma, UK) followed by extraction twice with phenol: chloroform: isoamyl alcohol and once with chloroform: isoamyl alcohol. The DNA was then precipitated with ethanol, collected by centrifugation, air-dried and resuspended in sterile distilled water.

\section{Comparative genomic hybridisation}

Comparative genomic hybridisation was performed using fluorochrome-conjugated DNAs (Kallioniemi et al, 1992; Visakorpi et al, 1995). In brief, tumour DNA was labelled with Spectrum Green (Vysis, UK) and normal human genomic placental reference DNA with Spectrum Red (Vysis, UK) by nick translation. Normal human lymphocyte metaphase preparations (Vysis, UK) were denatured at $72-74^{\circ} \mathrm{C}$ for $5 \mathrm{~min}$ in a denaturation solution $(70 \%$ formamide, $2 \times \mathrm{SSC}$, $\mathrm{pH} 5.3$ ), and dehydrated in an ethanol series $(70,85$, then $100 \%)$. A probe mixture comprising 400ng of labelled tumour DNA, 400ng of labelled reference DNA and $20 \mu \mathrm{g}$ of Cot- 1 DNA (Gibco BRL, UK) was denatured at $72-74^{\circ} \mathrm{C}$ for $5 \mathrm{~min}$ and applied to the normal lymphocyte metaphases and cohybridised at $37^{\circ} \mathrm{C}$ for 2 days. Posthybridisation washes were carried out in $0.4 \times \mathrm{SSC} / 0.3 \%\left(\mathrm{vv}^{-1}\right) \mathrm{NP}-40$ at $72-74^{\circ} \mathrm{C}$ for $2 \mathrm{~min}$, followed by $2 \times \mathrm{SSC} / 0.1 \%\left(\mathrm{v} \mathrm{v}^{-1}\right) \mathrm{NP}-40$ for $2 \mathrm{~min}$ at $20^{\circ} \mathrm{C}$. Slides were air-dried and counterstained with 4,6-diamidino-2-phenylindole (DAPI) in Vectashield antifade solution.

\section{Digital image analysis}

Hybridised metaphase spread images were visualised using a Zeiss Axioplan fluorescence microscope. Metaphase images for the three different colours blue (DAPI), Spectrum Red and Spectrum Green were collected using a cooled CCD camera (SenSys 1400) and stored as a three-colour image using the Vysis Quantitative Image Processing System (QUIPS). The chromosomes were identified based on their DAPI banding. The green-to-red fluorescence ratio profiles were automatically determined for each chromosome and a mean ratio profile combining 5-10 metaphase spreads was generated. A ratio of below 0.85 or above 1.15 was taken to indicate regions of under-representation (losses) or over-representation (gains), respectively. If the red-green ratio exceeded 1.5 in a small segment of a chromosome arm, the regions were considered to represent a high level of DNA amplification.

\section{Loss of heterozygosity}

Loss of heterozygosity $(\mathrm{LOH})$ in a total of 27 tumour specimens was examined with the following microsatellite markers: IFNA (9p21); D9S104 (9p13); HXB (9q32-34); D9S64 (9q34). The PCR reaction mixture contained $12.5 \mathrm{pmol}$ of each primer, one of which was fluorescently labelled, 0.75 U Taq DNA polymerase (Promega, UK), $1.5 \mathrm{~mm} \mathrm{MgCl}_{2}, 200 \mu \mathrm{m}$ each of dATP, dCTP, dTTP, dGTP and $50 \mathrm{ng}$ of sample DNA in a $20 \mu \mathrm{l}$ reaction volume. PCR amplification was performed in a thermal-cycler (Perkin-Elmer, UK). The conditions for amplification were $95^{\circ} \mathrm{C}$ for $5 \mathrm{~min}$, then 40 cycles of $95^{\circ}$ for $30 \mathrm{~s}, 58^{\circ}$ for $45 \mathrm{~s}$, and $72^{\circ} \mathrm{C}$ for $45 \mathrm{~s}$ with a final extension at $72^{\circ} \mathrm{C}$ for $5 \mathrm{~min}$. The PCR products were denatured and run on a $6 \%$ polyacrylamide denaturing gel in $1 \times$ Tris Boric Acid (TBE) buffer on a Model 377 Applied Biosystems automated fluorescent DNA sequencer, using a four-colour detection system. One microlitre from each PCR was combined with $4 \mu$ l formamide and $0.5 \mu \mathrm{l}$ of a fluorescent size marker solution (Applied Biosystems, UK). This mixture was denatured for $3 \mathrm{~min}$ at $90^{\circ} \mathrm{C}$ after which $5 \mu$ l was loaded into each well on the prewarmed gel. The gel was run for $4 \mathrm{~h}$ at $30 \mathrm{~W}$ and $50^{\circ} \mathrm{C}$.

The fluorescent gel data collected during the run were analysed using the Genescan Analysis program (ABI) at the end of the run. Allelic imbalance indicative of $\mathrm{LOH}$ was scored when there was more than $50 \%$ loss of intensity of one allele in the tumour sample compared to the matched allele from normal tissue (Cawkwell et al, 1993).

\section{RESULTS}

Thirty three cases of OCCC, presenting between 1976 and 1999, were identified from the pathological records of three institutions. Comparative genomic hybridisation was performed on 18 of these cases (case numbers 1-18). Twelve of the 18 CGH cases had sufficient tumour and normal material for confirmatory $\mathrm{LOH}$ markers also to be analysed. Loss of hetrozygosity marker analysis was also performed on an additional 15 cases (case numbers 1933) for which paired tumour and normal samples could be identified. In total, LOH was performed on 27 of the 33 OCCC cases.

\section{Clinical results}

The median age at diagnosis was 57 years (range 37-84). There were $20(61 \%)$ FIGO stage I, one $(3 \%)$ FIGO stage II, nine $(27 \%)$ FIGO stage III and three (9\%) FIGO stage IV cases. The median actuarial overall survival for all 33 cases was 3.7 years with a 5 year overall survival rate of $45 \%$ (95\% CI $28-62 \%)$.

\section{CGH results}

Genomic imbalances were detected in all 18 cases of OCCC examined by CGH (Figure 1, Table 1). Chromosomal losses were found more frequently than chromosomal gains, with a mean number of CGH changes (gains and losses) per case of 6 (range 115). No high-level amplifications were identified at the 1.5 threshold. Chromosome 9 was the most common site for genetic abnormalities with 10 of the 18 (55\%) cases showing deletion of $9 p$ and/or $9 q$ frequently altered, again showing a higher prevalence of losses than gains. Other common deletions included chromosome $1 \mathrm{p}$ (five cases, 28\%), chromosome 11q (four cases, 22\%) and chromosome 16p/q (five cases, 28\%). The most common sites of amplification were on chromosome 3 (six cases, 33\%) and chromosome 13q (four cases, 22\%).

\section{LOH results}

In view of the high rate of loss on chromosome 9, LOH marker analysis was performed as described. Six cases (case numbers 1, 2, 

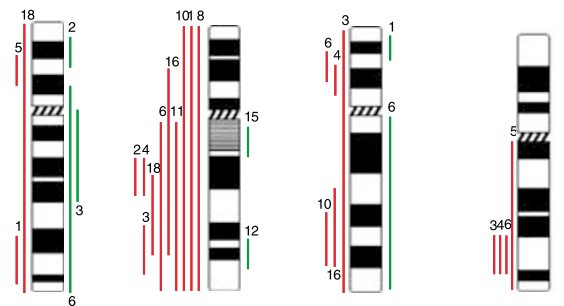

9

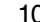

11

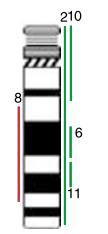

13

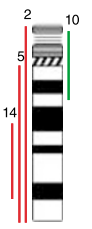

14

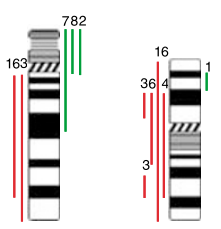

15

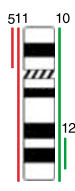

17

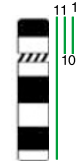

18

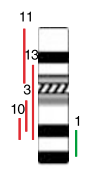

19

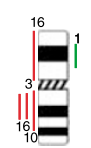

20

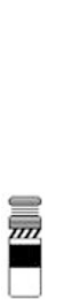

21

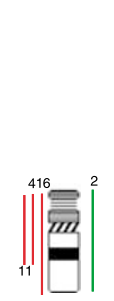

22

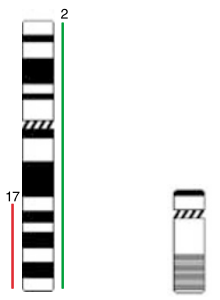

X
12

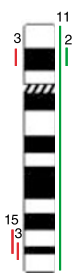

Y

Figure I Schematic representation of the chromosomal imbalances detected by CGH in 18 cases. Red vertical lines on the left-hand side represent chromosome deletion. Green vertical lines on the right-hand side represent chromosome amplification. Each line represents genetic aberrations in one case.

Table I Comparative genomic hybridisation findings in 18 clear cell ovarian carcinoma cases

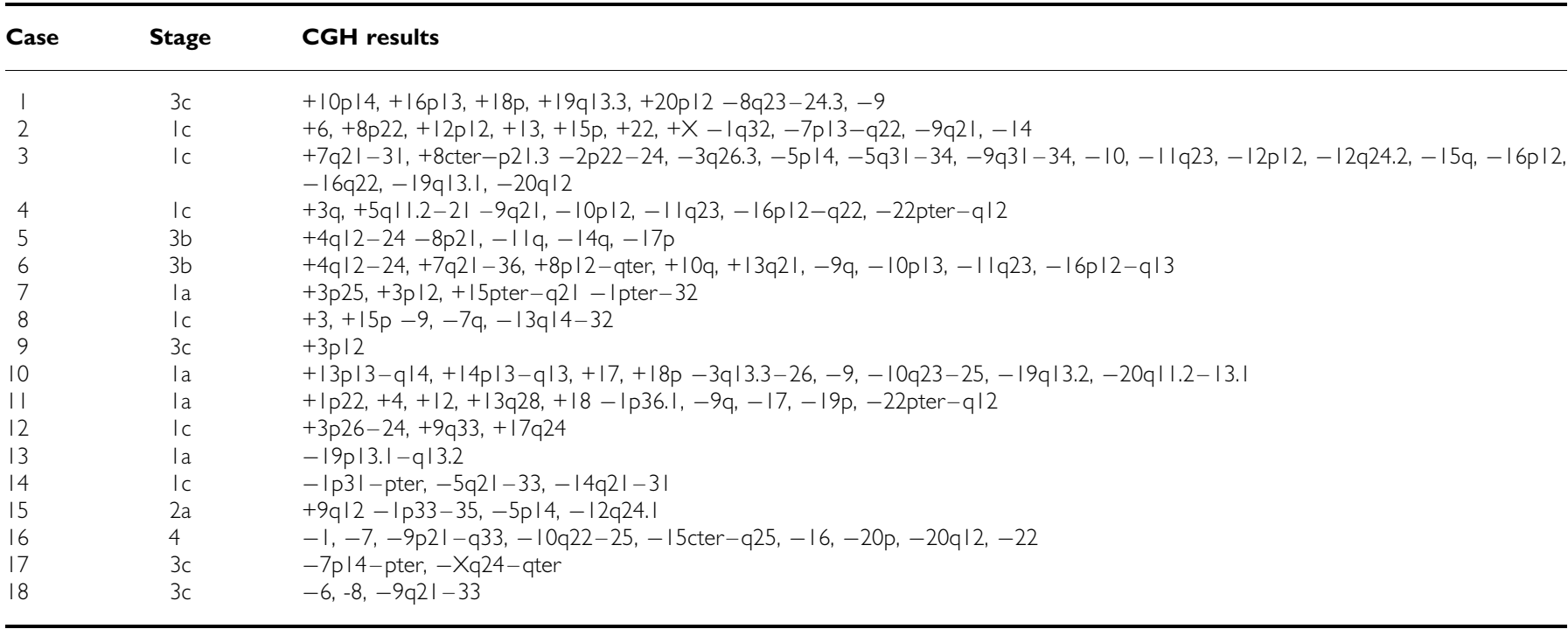

$3,4,10$ and 11) that had loss seen on chromosome 9 with CGH had confirmatory LOH studies carried out. Loss of heterozygosity was identified in at least one locus on chromosome 9 in all of these six cases. In total, combining all $27 \mathrm{LOH}$ cases, $\mathrm{LOH}$ was observed in 11 cases (41\%) at IFNA marker (9p21), seven cases $(26 \%)$ at D9S104 (9p13), nine cases (33\%) at HXB (9q32-34) and 10 cases $(37 \%)$ at D9S64 (9q34) (Figure 2).

\section{DISCUSSION}

This study has assessed the cytogenetic abnormalities in a cohort of ovarian cancers with pure clear cell histology. Comparative genomic hybridisation performed on 18 cases identified frequent deletions of chromosome $9 \mathrm{p}, 1 \mathrm{p}, 11 \mathrm{q}$ and $16 \mathrm{p} / \mathrm{q}$ and amplifications of 3 and13q. 


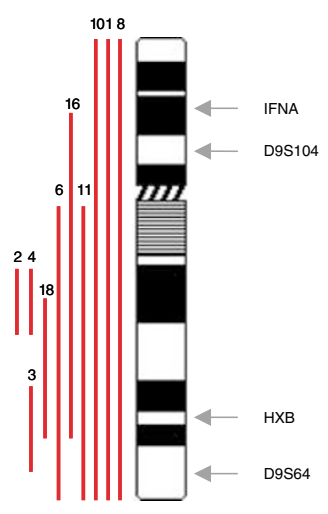

\begin{tabular}{|c|c|c|c|c|c|c|c|c|c|c|c|c|c|c|c|c|c|c|c|c|c|c|c|c|c|c|c|}
\hline & \multicolumn{27}{|c|}{ Case number } \\
\hline & \multicolumn{12}{|c|}{ CGH cases with LOH } & \multicolumn{15}{|c|}{ LOH only cases } \\
\hline & 1 & 2 & 3 & 4 & 7 & 9 & 10 & 11 & 12 & 14 & 15 & 17 & 19 & 20 & 21 & 22 & 23 & 24 & 25 & 25 & 27 & 28 & 29 & 30 & 31 & 32 & 33 \\
\hline $\begin{array}{l}\text { IFNA } \\
9 p 21\end{array}$ & $\Delta$ & & $\Delta$ & $\Delta$ & $\Delta$ & $\Delta$ & $\Delta$ & & $\Delta$ & & & $\Delta$ & $\Delta$ & $\Delta$ & & $\Delta$ & $\Delta$ & $\Delta$ & $\Delta$ & $\Delta$ & $\Delta$ & & $\Delta$ & $\Delta$ & $\Delta$ & & $\Delta$ \\
\hline $\begin{array}{l}\text { D9S } 104 \\
9 \mathrm{p} 13\end{array}$ & & $\Delta$ & & $\Delta$ & & $\Delta$ & $\Delta$ & $\Delta$ & $\Delta$ & & & $\Delta$ & $\Delta$ & & $\Delta$ & $\Delta$ & & & $\Delta$ & $\Delta$ & & & $\Delta$ & & & $\Delta$ & $\Delta$ \\
\hline $\begin{array}{l}\text { HXB } \\
9 q 32-34\end{array}$ & & $\Delta$ & & $\Delta$ & $\Delta$ & $\Delta$ & $\Delta$ & $\Delta$ & $\Delta$ & & $\Delta$ & & $\Delta$ & $\Delta$ & $\Delta$ & $\Delta$ & & $\Delta$ & $\Delta$ & $\Delta$ & & & $\Delta$ & $\Delta$ & $\Delta$ & $\Delta$ & $\Delta$ \\
\hline $\begin{array}{l}\text { D9S } 64 \\
\text { 9q34 }\end{array}$ & $\Delta$ & $\Delta$ & $\Delta$ & $\Delta$ & & $\Delta$ & $\Delta$ & $\Delta$ & $\Delta$ & $\Delta$ & $\Delta$ & & & $\Delta$ & $\Delta$ & $\Delta$ & & $\Delta$ & $\Delta$ & $\Delta$ & $\Delta$ & $\Delta$ & $\Delta$ & $\Delta$ & $\Delta$ & $\Delta$ & \\
\hline
\end{tabular}

Figure 2 Chromosome $9 \mathrm{LOH}$ marker results with chromosome 9 ideogram. Loss of heterozygosity was performed on a total of 27 cases. The case numbers on the left represent LOH cases for which CGH was also performed (see Table I). The remaining cases (numbered I-I5) had LOH alone performed.

Analysis of the three main histological ovarian subtypes (serous, mucinous and endometrioid) has demonstrated distinct karyotypes with gains at $17 \mathrm{q}$ more frequent in mucinous tumours with gains at $1 \mathrm{q}, 10 \mathrm{q}$ and $11 \mathrm{q}$ seen more commonly in serous and endometrioid tumours (Tapper et al, 1997). However, CGH analysis of fallopian tube carcinoma has demonstrated similarities with serous carcinoma of both uterus and ovary (Pere et al, 1998). Our results suggest that the pattern of genomic alterations found in clear cell ovarian tumours is distinct from that seen in other ovarian histological subtypes. A recent analysis of ovarian cancer using oligonucleotide microarrays has demonstrated distinct patterns of gene expression for the different morphological subtypes. In clear cell tumours, 73 genes, with a two- to 29 -fold increase in expression, were identified which distinguished it from other ovarian subtypes (Schwartz et al, 2002).

The cytogenetics of 12 cases of clear cell ovarian carcinoma assessed by CGH has been reported by Suehiro et al (2000). This Japanese study, which included eight cases of FIGO stage I disease, demonstrated amplification of chromosome $8 \mathrm{q}$ in eight cases (67\%). Increased copy number was also frequently identified on chromosomes $17 \mathrm{q}$ and $20 \mathrm{q}$; reduced copy number of $19 \mathrm{p}$ was also identified; chromosome 9 deletions were only seen in two cases (17\%). No LOH analysis was performed either to confirm or further define these changes.

These results are distinct to those obtained in the current study, where amplification of chromosome 8 was infrequent and deletion of chromosome $9 \mathrm{p}$ and $\mathrm{q}$ was common. The reason for these differences is not clear. However, in many Japanese studies the incidence of clear cell histology in epithelial ovarian carcinoma is as high as $15.3 \%$ (Sugiyama et al, 2000). This differs significantly from an incidence of approximately $5 \%$ seen in American or European studies (Omura et al, 1991; O’Brien et al, 1993). It is not clear whether this reflects differences in the diagnostic criteria used to define the clear cell phenotype in Japan, or differences in the molecular genetics of ovarian cancer in Japanese women. Other CGH studies of ovarian cancer of all histological subtypes have identified deletions of chromosome 9p; a study of 24 cases of grade 1 or 2 ovarian cancers reported 9p loss in six cases (25\%; (Tapper et al, 1997)). A larger study of 106 cases of all histological grades identified 9p loss in $41 \%$ of patients (Kiechle et al, 2001).

The LOH analysis of chromosome 9 performed herein, confirmed the CGH results obtained in this study and was consistent with other published data (Chenevix-Trench et al, 1994). A detailed analysis of chromosome 9 in 33 ovarian tumours of various grades and stages detected LOH in 26 cases $(79 \%)$ and proposed three specific regions of deletion - one at 9p21 and two on 9q; one proximal, one distal (Devlin et al, 1996). During the last few years, these three regions of deletion have been examined in detail in attempts to identify tumour suppressor genes whose function is lost in a variety of ovarian cancers.

The locus at $9 \mathrm{p} 21$, deleted in 11 of the 20 informative cases $(55 \%)$ in this study, includes the cyclin-dependent kinase inhibitor 2 (CDKN2) locus, a region now known to encode the proteins CDKN2A/p16(INK4A), CDKN2B/p15(INK4B) and an alternative reading frame of $C D K N 2 A$, p14ARF (Kamb et al, 1994; Stott et al, 1998). These three proteins act as tumour suppressor genes through the two central growth control pathways, which act upon $\mathrm{Rb}$ and $\mathrm{p} 53$ (Saegusa et al, 2001). Deletion or inactivation of genes within this region is a frequent cytogenetic abnormality in other malignancies such as melanoma (Kamb et al, 1994), bladder cancer (Cairns et al, 1995) and renal cancer (Schraml et al, 2001). In the past, OCCC has been confused with metastatic renal cell carcinoma (Young and Hart, 1992) and it is interesting to note that chromosome 9 loss has also been found in renal clear cell tumour with 33\% having partial or complete deletion of chromosome 9 (Cairns et al, 1995).

The data we have obtained suggest a role for one or more of the gene products from this locus in the molecular pathogenesis of clear cell ovarian carcinoma. The expression of CDKN2A/ p16(INK4A) in ovarian carcinoma has been assessed in a number of studies with conflicting results. P16 overexpression has been reported in 22 of $24(90 \%)$ high-stage malignant ovarian tumours (Shigemasa et al, 1997), whereas other reports suggest a correlation between p16 underexpression and low-grade ovarian tumours; 22 out of 60 (37\%) (Fujita et al, 1997).

The deletions seen within chromosome $9 \mathrm{q}$ by both CGH and LOH in our study may also imply a role for alternative tumour suppressor genes in the molecular pathogenesis of clear cell ovarian carcinoma. The distal locus on $9 \mathrm{q}$ includes two genes with potential roles as tumour suppressor genes in ovarian cancer; the TSC1 gene at 9q34 (Miloloza et al, 2000) and the DBCCR1 gene at 9q32-33 (Habuchi et al, 1998). The specific roles of these genes in the pathogenesis and prognosis of ovarian cancer have not previously been assessed.

The other frequent genetic abnormalities seen in this study include deletion on chromosome $16 \mathrm{p}$ and $16 \mathrm{q}$ and amplification of chromosome 3p and 3q. Allele loss on 16q has been connected with progression of some cancer types, including breast and lung (Lee, 1996; Sato et al, 1998). 16q deletions were observed in 14 of 21 (67\%) high-grade epithelial ovarian tumours (Kawakami et al, 1999). Candidate genes that map to this region include $\mathrm{CDH} 13(\mathrm{H}-$ cadherin; 16q24). This gene belongs to the family of cell adhesion molecules of which E-cadherin is a well-recognised tumour suppressor gene in gastric cancer (Becker et al, 1994). Copy number increases of chromosome $3 \mathrm{q}$ in ovarian carcinomas have previously been reported (Arnold et al, 1996; Sonoda et al, 1997) 
and mapped to a region at 3q26 containing PIK3CA (Shayesteh et al, 1999). Furthermore, upregulation of this gene has been seen in $36 \%$ of malignant, mostly serous, high-grade ovarian carcinomas (Sonoda et al, 1997). PIK3CA encodes a subunit of a phosphatidylinositol 3-kinase involved in kinase-mediated cell signalling (Rodriguez-Viciana et al, 1996). Other published work has also found that copy number alterations in ovarian cancer correlates to histological tumour grade with an overall increase in DNA sequence copy number abnormalities seen in high-grade tumours as opposed to low-grade tumours (Iwabuchi et al, 1995). Specifically, 3q alterations were reported in high-grade tumour cases with an increased copy number on $3 q 25-26$ found in 13 out of 26 cases $(50 \%)$.

\section{REFERENCES}

Arnold N, Hagele L, Walz L, Schempp W, Pfisterer J, Bauknecht T, Kiechle M (1996) Overrepresentation of $3 q$ and $8 \mathrm{q}$ material and loss of $18 \mathrm{q}$ material are recurrent findings in advanced human ovarian cancer. Genes Chromosomes Cancer 16: $46-54$

Becker KF, Atkinson MJ, Reich U, Becker I, Nekarda H, Siewert JR, Hofler $\mathrm{H}$ (1994) E-cadherin gene mutations provide clues to diffuse type gastric carcinomas. Cancer Res 54:3845-3852

Cairns P, Tokino K, Eby Y, Sidransky D (1995) Localization of tumour suppressor loci on chromosome 9 in primary human renal cell carcinomas. Cancer Res 55: 224-227

Cawkwell L, Bell SM, Lewis FA, Dixon MF, Taylor GR, Quirke P (1993) Rapid detection of allele loss in colorectal tumours using microsatellites and fluorescent DNA technology. Br J Cancer 67: 1262-1267

Chenevix-Trench G, Kerr J, Friedlander M, Hurst T, Sanderson B, Coglan M, Ward B, Leary J, Khoo SK (1994) Homozygous deletions on the short arm of chromosome 9 in ovarian adenocarcinoma cell lines and loss of heterozygosity in sporadic tumours. Am J Hum Genet 55: $143-149$

Clark TG, Stewart ME, Altman DG, Gabra H, Smyth JF (2001) A prognostic model for ovarian cancer. $\mathrm{Br} J$ Cancer 85: $944-952$

Devlin J, Elder PA, Gabra H, Steel CM, Knowles MA (1996) High frequency of chromosome 9 deletion in ovarian cancer: evidence for three tumoursuppressor loci. Br J Cancer 73: 420-423

Fujita M, Enomoto T, Haba T, Nakashima R, Sasaki M, Yoshino K, Wada H, Buzard GS, Matsuzaki N, Wakasa K, Murata Y (1997) Alteration of p16 and p15 genes in common epithelial ovarian tumours. Int J Cancer 74: $148-155$

Gallion HH, Powell DE, Smith LW, Morrow JK, Martin AW, van Nagell JR, Donaldson ES (1990) Chromosome abnormalities in human epithelial ovarian malignancies. Gynecol Oncol 38: 473-477

Gatta G, Lasota MB, Verdecchia A (1998) Survival of European women with gynaecological tumours, during the period 1978-1989. EUROCARE Working Group. Eur J Cancer 34: 2218-2225

Goff BA, Sainz dlC, Muntz HG, Fleischhacker D, Ek M, Rice LW, Nikrui N, Tamimi HK, Cain JM, Greer BE, Fuller AF (1996) Clear cell carcinoma of the ovary: a distinct histologic type with poor prognosis and resistance to platinum-based chemotherapy in stage III disease. Gynecol Oncol 60: $412-417$

Habuchi T, Luscombe M, Elder PA, Knowles MA (1998) Structure and methylation-based silencing of a gene (DBCCR1) within a candidate bladder cancer tumor suppressor region at 932-933. Genomics 48: $277-288$

Iwabuchi H, Sakamoto M, Sakunaga H, Ma YY, Carcangiu ML, Pinkel D, Yang-Feng TL, Gray JW (1995) Genetic analysis of benign, low-grade, and high-grade ovarian tumors. Cancer Res 55: 6172-6180

Jackson DP, Lewis FA, Taylor GR, Boylston AW, Quirke P (1990) Tissue extraction of DNA and RNA and analysis by the polymerase chain reaction. J Clin Pathol 43: 499-504

Kallioniemi A, Kallioniemi OP, Sudar D, Rutovitz D, Gray JW, Waldman F, Pinkel D (1992) Comparative genomic hybridization for molecular cytogenetic analysis of solid tumors. Science 258: $818-821$

Kamb A, Gruis NA, Weaver-Feldhaus J, Liu Q, Harshman K, Tavtigian SV, Stockert E, Day III RS, Johnson BE, Skolnick MH (1994) A cell cycle regulator potentially involved in genesis of many tumor types. Science 264: $436-440$
The cytogenetic abnormalities detected by the present study reflect many of those previously identified in other histological subtypes of ovarian cancer (Sonoda et al, 1997; Tapper et al, 1997). No genetic change unique to the clear cell histology was identified. Further characterisation of candidate genes within the regions of deletion/amplification is underway.

\section{ACKNOWLEDGEMENTS}

We are grateful to the Cancer Research UK and to Yorkshire Cancer Research for their support and funding of this project.

Kawakami M, Staub J, Cliby W, Hartmann L, Smith DI, Shridhar V (1999) Involvement of $\mathrm{H}$-cadherin $(\mathrm{CDH} 13)$ on $16 \mathrm{q}$ in the region of frequent deletion in ovarian cancer. Int J Oncol 15: 715-720

Kennedy AW, Biscotti CV, Hart WR, Webster KD (1989) Ovarian clear cell adenocarcinoma. Gynecol Oncol 32: $342-349$

Kiechle M, Jacobsen A, Schwarz-Boeger U, Hedderich J, Pfisterer J, Arnold $\mathrm{N}$ (2001) Comparative genomic hybridization detects genetic imbalances in primary ovarian carcinomas as correlated with grade of differentiation. Cancer 91: $534-540$

Koshiyama M, Fujii H, Konishi M, Nanno H, Hayashi M, Tauchi K, Yoshida M (1999) Recurrent clear cell carcinoma of the ovary changing into producing parathyroid hormone-related protein (PTH-rP) with hypercalcemia. Eur J Obstet Gynecol Reprod Biol 82: 227-229

Lee SW (1996) H-cadherin, a novel cadherin with growth inhibitory functions and diminished expression in human breast cancer. Nat Med 2: $776-782$

Miloloza A, Rosner M, Nellist M, Halley D, Bernaschek G, Hengstschlager M (2000) The TSC1 gene product, hamartin, negatively regulates cell proliferation. Hum Mol Genet 9: 1721-1727

O'Brien ME, Schofield JB, Tan S, Fryatt I, Fisher C, Wiltshaw E (1993) Clear cell epithelial ovarian cancer (mesonephroid): bad prognosis only in early stages. Gynecol Oncol 49: 250-254

Omura GA, Brady MF, Homesley HD, Yordan E, Major FJ, Buchsbaum HJ Park RC (1991) Long-term follow-up and prognostic factor analysis in advanced ovarian carcinoma: the Gynecologic Oncology Group experience. J Clin Oncol 9: 1138-1150

Pere H, Tapper J, Seppala M, Butzow R (2002) Genomic alterations in fallopian tube carcinoma: comparison to serous uterine and ovarian carcinoma reveals similarity suggesting likeliness in molecular pathogenesis. Cancer Res 58: $4274-4276$

Recio FO, Piver MS, Hempling RE, Driscoll DL (1996) Lack of improved survival plus increase in thromboembolic complications in patients with clear cell carcinoma of the ovary treated with platinum versus nonplatinum-based chemotherapy. Cancer 78: 2157-2163

Roberts CG, Tattersall MH (2001) Cytogenetic study of solid ovarian tumours. Cancer Genet Cytogenet 48(2): 243-253.

Rodriguez-Viciana P, Marte BM, Warne PH, Downward J (1996) Phosphatidylinositol $3^{\prime}$ kinase: one of the effectors of Ras. Philos Trans $R$ Soc London B Biol Sci 351: 225-231

Sato M, Mori Y, Sakurada A, Fujimura S, Horii A (1998) The H-cadherin (CDH13) gene is inactivated in human lung cancer. Hum Genet 103: $96-$ 101

Saegusa M, Machida BD, Okayasu I (2001) Possible associations among expression of p14(ARF), p16(INK4a), p21(WAF/CIP1), p27(KIP1), and p53 accumulation and the balance of apoptosis and cell proliferation in ovarian carcinomas. Cancer 92: 1177-1189

Schraml P, Struckmann K, Bednar R, Fu W, Gasser T, Wilber K, Kononen J, Sauter G, Mihatsch MJ, Moch H (2001) CDKNA2A mutation analysis, protein expression, and deletion mapping of chromosome $9 \mathrm{p}$ in conventional clear-cell renal carcinomas: evidence for a second tumor suppressor gene proximal to CDKN2A. Am J Pathol 158: 593-601

Schwartz DR, Kardia SL, Shedden KA, Kuick R, Michailidis G, Taylor JM, Misek DE, Wu R, Zhai Y, Darrah DM, Reed H, Ellenson LH, Giordano TJ, Fearon ER, Hanash SM, Cho KR. (2002). Gene expression in ovarian cancer reflects both morphology and biological behavior, distinguishing 
clear cell from other poor-prognosis ovarian carcinomas. Cancer Res 62: $4722-4729$.

Shayesteh L, Lu Y, Kuo WL, Baldocchi R, Godfrey T, Collins C, Pinkel D, Powell B, Mills GB, Gray JW (1999) PIK3CA is implicated as an oncogene in ovarian cancer. Nat Genet 21: 99-102

Shigemasa K, Hu C, West CM, Clarke J, Parham GP, Parmley TH, Lorourian S, Baker W, O'Brien TJ (1997) p16 overexpression: a potential early indicator of transformation in ovarian carcinoma. J Soc Gynecol Invest 4: $95-102$

Sonoda G, Palazzo J, Du MS, Godwin AK, Feder M, Yakushiji M, Testa JR (1997) Comparative genomic hybridization detects frequent overrepresentation of chromosomal material from 3q26, 8q24, and $20 \mathrm{q} 13$ in human ovarian carcinomas. Genes Chromosomes Cancer 20: $320-328$

Stott FJ, Bates S, James MC, McConnell BB, Starborg M, Brookes S, Palmero I, Ryan K, Hara E, Vousden KH, Peters G (1998) The alternative product from the human CDKN2A locus p14(ARF), participates in a regulatory feedback loop with p53 and MDM2. EMBO J 17: 5001-5014

Suehiro Y, Sakamoto M, Umayahara K, Iwabuchi H, Sakamoto H, Tanaka N, Takeshima N, Yamauchi K, Hasumi K, Akiya T, Sakunaga H, Muroya T, Numa F, Kato H, Tenjin Y, Sugishita T (2000) Genetic aberrations detected by comparative genomic hybridization in ovarian clear cell adenocarcinomas. Oncology 59: 50-56

Sugiyama T, Kamura T, Kigawa J, Terakawa N, Kikuchi Y, Kita T, Suzuki M, Sato I, Taguchi K (2000) Clinical characteristics of clear cell carcinoma of the ovary: a distinct histologic type with poor prognosis and resistance to platinum-based chemotherapy. Cancer 88: 2584-2589

Taetle R, Aickin M, Yang JM, Panda L, Emerson J, Roe D, Adair L, Thompson F, Liu Y, Wisner L, Davis JR, Trent J, Alberts DS (1999) Chromosome abnormalities in ovarian adenocarcinoma: I. Nonrandom chromosome abnormalities from 244 cases. Genes Chromosomes Cancer 25: $290-300$

Tapper J, Butzow R, Wahlstrom T, Seppala M, Knuutila S (1997) Evidence for divergence of DNA copy number changes in serous, mucinous and endometrioid ovarian carcinomas. Br J Cancer 75: $1782-1787$

Visakorpi T, Kallioniemi AH, Syvanen AC, Hyytinen ER, Karhu R, Tammela T, Isola JJ, Kallioniemi OP (1995) Genetic changes in primary and recurrent prostate cancer by comparative genomic hybridization. Cancer Res 55: $342-347$

Young RH, Hart WR (1992) Renal cell carcinoma metastatic to the ovary: a report of three cases emphasizing possible confusion with ovarian clear cell adenocarcinoma. Int J Gynecol Pathol 11: 96-104 